\title{
From Exclusion to Informal Segregation: The Limits to Racial Transformation at the University of Natal
}

\section{Kevin Durrheim, Kirsty Trotter, Desiree Manicom and Laurence Piper}

\begin{abstract}
In the context of higher education transformation in South Africa, this paper attempts to capture a series of observations about transformation at the former University of Natal. From a descriptive, multidisciplinary perspective it critiques racial transformation at the University as driven by concerns of representivity over the need for desegregation. We base this discussion on three sets of observations: an analysis of institutional policy, a review of demographic change in the staff and student bodies and a study of students. lived experiences of segregation on campus. During the past decade a great deal of change has occurred in the overall racial demographics of the student and staff bodies. While demographic transformation efforts at the University do echo national trends, a closer inspection of the policy, practice and lived experience of transformation at the University reveals that all is not well. In particular, institutional policy with respect to transformation has tended to be reactive and superficial and students experience campus as a segregated and racialized space. Thus, racial transformation at the University has only been partially successful: while overt racist exclusion is withering, informal segregation and attendant racialization remain.
\end{abstract}

\section{Introduction}

The shift away from apartheid has been effected, in part, by the passing of legislation which outlawed racism in both the public and private spheres, and which compelled all institutions to adopt various policies of redress. Given the long history of racism in tertiary education, this legislation had placed significant transformation demands on institutions. In the early 1990s Harleston predicted that "South African colleges and universities will be 
under considerable pressure to assume a pro-active role in ensuring access, equity and educational opportunities. This pressure will reflect new political realities, restructured systems of primary and secondary education, demographic shifts in urban centres, changing societal values and economic forces related to the country's challenge to improve the quality of life for all citizens and to compete successfully in global markets" (cited in Kaplan, 1994: 267).

By 1994 the South African education system was experiencing a series of major challenges directly related to apartheid educational policy (Cloete et al., 2002). Firstly, it was characterized by inequitable distribution of access and opportunity for students and staff along the lines of class, race, gender and geography. Secondly, there was too much academic insularity and closed system disciplinary programmes. Thirdly, governance of higher education was fragmented, inefficient and ineffective. Thus, the "challenge for the new South Africa was to transform the higher education system from one that satisfied none of the imperatives of equity, efficiency and development to one that would meet all three of these national goals" (Cloete, 2002: 99). Since 1994, in an effort to address the wrongs of the past, and to align itself with international standards of best practice, the tertiary educational sector in South Africa has "been heavily engaged with the social reconstruction agenda" (Brennan cited in Enders and Fulton, 2002: 75).

There have been two major policy interventions. The first was the establishment of the National Commission on Higher Education (NCHE) whose self-identified agenda was "to preserve what is valuable and to address what is defective and requires transformation" (Cloete, 2002: 94). The recommendations made by the NCHE included massification of the system, planning for growth, improving throughput rates, and increasing postgraduate enrolments (NCHE, 1996). The second major policy intervention was the Higher Education Act of 1997, which responded to the recommendations by the NCHE and identified a number of priorities and intervention strategies. The main focus of the Act was to increase access to higher education by the wider population, to improve the quality and relevance of research outputs, and thus contribute towards the development of a skilled citizenry, equipped to compete in a rapidly changing international context (Department of Education, 1997, 2001).

Multiple lines of intervention were necessary to achieve these aims. Transforming the governance of tertiary institutions was crucial to achieve a single coordinated system that would be responsive to the needs of the new 
democracy and cost effective. This effectively involved desegregating the fragmented apartheid system of higher education. Although this paved the way for a non-racial education system, issues of equity and access also had to be addressed. The Act devolved responsibility for this to institutions. The Preamble to the Act, states, for example, that institutions need to "Redress past discrimination and ensure representivity and equal access". The Council for Higher Education (established in terms of the act) is also mandated to "promote the access of students to higher education institutions" (Chapter 2: pp. 4-19). The Act also ensures that various institutional bodies are in place within institutions to implement various policy strategies. One of these is the Institutional Forum which is required to address "race and gender equity policies" (Chapter 4: pp.26-38). Importantly, too, the Act ensures that "The admission policy of a public higher education institution must provide appropriate measures for the redress of past inequalities and may not unfairly discriminate in any way" (ibid).

In their major overview of transformation the tertiary education, Cooper and Subotsky (2001) suggest that these policy aims have only been partially achieved. There has been a dramatic change in the representivity of the student population serviced by the tertiary education sector. Although the press have reported "hastily constructed and far reaching conclusions ... [about] 'the massive sudden decline in African enrolments'" (Cooper and Subotsky, 2001: 269), Cooper and Subotsky suggest that this is not the case. On the contrary, they found that the proportion of African students increased from one fifth of the total in 1984 to more than half in 1998; and they characterised this as a "dramatic revolution". However, they claim that this "revolution" is "skewed" (ibid: 26), and suggest that such overall demographic changes need to be disaggregated by field, qualification and gender to gain a fuller picture of change.

This paper provides a multifaceted investigation of transformation, as it has unfolded on the ground at one South African institution, namely the former University of Natal (henceforth, UN). ${ }^{1}$ One of the prime aims of the paper is to provide the kind of disaggregated analysis of student and staff demographics recommended by Cooper and Subotsky (2001). We find that the skewed revolution has taken place in this context too. A great deal of change has happened, primarily in respect of the overall racial demographics ${ }^{2}$ of the student and staff bodies. Simply put, in race terms, the people at the University look more like the broader South African population every year, a 
fact that the University often cites as evidence of the success of racial transformation. However, the disaggregated analysis shows significant unevenness in this demographic shift.

In addition to this investigation of demographic changes, this paper aims to explore two features of the institutional context that can help us to understand why, as Brennan (cited in Enders and Fulton, 2002:75) argues, the institution - like others in the country - has not fully achieved its intended goals of transformation in terms of access, curriculum and institutional diversity. In the first part of the paper we comment on policy development during this period to study the self-reflexive (cognitive) response of the institution to the demands of transformation. We show that UN came to respond to transformation in a reactive way, understanding transformation in narrow demographic terms such as 'getting the racial numbers right'. Finally, after presenting the demographic analysis, we report the results of two investigations of the perceptions and experiences of students regarding racial interaction on campus. The results suggest an enduring reality of racial segregation on campus; a reality experienced in terms very similar to the race relations of old: marginalization, disempowerment, distrust, rivalry and tension.

Our overall conclusion is that demographic change and racial inclusion has not meant the demise of many of the aspects of racism that motivated transformation in the first place. Transformation policy must be directed to achieve Arnove's vision: "not only must higher education structures and campus environment ... change but most essentially, transformations in the attitudes and behaviours of individuals as they are manifested in administrative and pedagogical practices and interpersonal relations have to occur" (cited in Mabokela and King, 2001: viii).

\section{Transformation Policy}

In exploring the course of action taken by $\mathrm{UN}$ to respond to the national call for higher education transformation we conducted a thorough review of 38 national government and UN policy documents and statements, other published documents and previous research papers, all gathered from the UN archives (see Appendix). In addition, in the course of the 2002 academic year, interviews were conducted with several prominent members of the UN community. These included the Dean of Student Development, the Human Resources Manager, the Head of the School of Human and Social Studies and 
a visiting Fulbright scholar whose brief it had been to examine student demographics.

In spite of the 1959 Extension of University Education Act, which removed UN's right to decide who attended the institution, UN has prided itself on its "liberal position" under apartheid and this is often cited in official documentation (see Partners in Progress, 1995; A University in Transformation, 1996). To institutionalise this position the Academic Planning and Policy Committee began, in 1982, the process of developing a new and more socially responsive Mission Statement for UN. With this in place the process of developing policy on issues of transformation began actively in 1988, and culminated in the document entitled The Role in Society of the University: 1989 Onwards. It stated unequivocally "The University of Natal rejects apartheid. It is an equal opportunities and affirmative action University" (p.20)

At the forefront of this transformation process was the ViceChancellor's Review, which took four years to complete. This multi-phased process began by reviewing the management, administration and committee structures of UN in an attempt to enhance the efficiency of the institution. What followed was explicit attention to three specific areas of transformation. The first and most prominent are of concern was the student population. Of particular importance was increasing black student numbers in the face of an anticipated sharp decrease in government funding. Newspapers drew attention to the fact that "state subsidy to universities now met only 64 percent of the allocated budget at most universities" (Chishlom, Motala and Vally, 2003: 11). Two other issues to be discussed were the democratisation of the University's governance and the need for equal opportunity policies for both staff and student selection (Vice-Chancellor's Review Phase II Working Paper, September 1992).

The creation of the Labour Relations Act no. 66 of 1995 that set out various guidelines on integration in the work place, and the establishment of the National Commission on Higher Education began to impact on the policy action taken by the institution. In response to the Labour Relations Act, the University issued the Equal Opportunity and Affirmative Action Policy (1995) aimed at eliminating all forms of discrimination and appointing staff from previously disadvantaged groups-an implementation process to occur over five years. 
After the passing of the Higher Education Act of 1997, the University responded with the introduction of the Equity Access Program and the Academic Accelerated Promotions policy. In 1998 the Government passed the Employment Equity Act no.55 of 1998. This Act stipulated the rules and procedures that institutions were required to follow in order to ensure employment equity and the elimination of discrimination in the work place.

These two national policy interventions were to have a great influence on UN policy for the next three years. The first evidence of the University's commitment to achieving the aims of these policies this was in 1999 when, in response to the Employment Equity Act of 1998, the University established the Equal Opportunity and Affirmative Action Committee. As stipulated by the Act, an equity manager was employed for the University. Although the University had previously made moves in regards to employment equity, such as the equal access programme in 1997, the establishment of equity manager and the Equal Opportunity and Affirmative Action Committee was a direct result of government intervention in higher education institutions. The Equal Opportunity and Affirmative Action Committee proved to be instrumental in the creation of University policy for the next few years. By 2001 the newly formed Employment Equity Office set up a website on the UN inner web in order to make University policy available to the general public and students. The problem of attracting black academics to the University was flagged as the major obstacle to transformation (Employment Equity Plan, 2001).

In 2002 a shift in policy emphasis occurred with the University placing importance on its role in creating a new kind of citizenship in South Africa. Evidence of this focus existed in the Strategic Initiatives of 2000 and 2001 under new paragraphs entitled 'Life-Long Learning' and 'ResearchContributing to the Global Knowledge Economy'. Once again, this spoke directly to the developmental priorities highlighted by the National Commission on Higher Education and the Higher Education Policy of 1997.

In sum, beginning in the early 1990s much of the policy documentation pertaining to transformation emphasized the need to attract students from different racial backgrounds to the predominantly white institution. Midway through the decade the emphasis shifted towards to transforming staff demographics. In the first years of the $21^{\text {st }}$ century, the emphasis was on "special programmes" such as "life long learning" as a means of ensuring accessibility to higher education for all South Africans. Reflecting on this review of the policy documentation two main observations can be made. The first is that change appears to have been reactive rather than 
self initiated and the second is that the university's engagement with transformation has been somewhat superficial, lacking in creativity and policy-making initiative.

\section{Reactive Transformation}

For the most part, the University has shown an inclination to follow the lead of the government, to respond reactively, rather than initiating policy. The major influence has come from the National Education Policy Investigation in 1993, which prompted the University to assess its own position regarding transformation and resulted in the implementation of the 'Quality with Equity' strategy. Later, the Labour Relations Act of 1995 resulted in the creation of the University's Equal Opportunity and Affirmative Action Policy (1995). The Higher Education Act of 1997 played a major role in the creation by the University of the equity access programme as well as the academic accelerated promotions policy. The Employment Equity Act of 1998 led to the installation of the Equal Opportunity and Affirmative Action Committee and appointment of an Equity Manager on campus.

The indication is that this trend is being overtaken by a degree of initiative on the part of the institution. Indeed, in early 2002 the Policy and Strategy for Attracting More Africans to Academia was published which included the 'grow your own timber programme'. This programme included measures to allow more African students access to post graduate studies as well as affording potential African academics a chance to develop skills.

\section{Superficial Transformation}

The University's engagement in transformation has been superficial in three ways. First, during the period of documentation under analysis very little had changed in the text of the policy documents. We found that many of the comments and statements offered in the first strategic policy documents were simply transplanted into later documents. In fact, many of the documents had a cut-and-paste feel. Second, the policy documents outlined broad policy objectives rather than specific planned policy interventions. Although Government policy in the early 1990 s was itself broad in nature, the University did little to develop clear programmes for implementation or budget estimates, with the consequence that its own initiatives were more like statements of intent than policy programmes. These statements of intent are scattered throughout the institution's transformation policy archive, including for example the 1992 Vice-Chancellor's Review. There were a few exceptions 
to this rule, like 'Teach-Test-Teach' programme briefly instituted in the early 1990 s, but the general finding holds. Finally, transformation in the student and staff bodies had been understood primarily in quantitative terms. Transformation progress is presented by summarising changes in staff and student demographics, and little attention is given to the quality of interaction between groups.

\section{Racial Demographic Change}

In this section we explore the extent and nature of the transformation of UN's racial demography. In so doing, we examine the statistics of student numbers at the Pietermaritzburg campus, and staff numbers at the University as a whole, from 1994 to 2002 . These statistics were collected by the University administration, and were made available to us by the Information Management Division ${ }^{3}$. The accuracy of these statistics is suggested by the fact that they are the same statistics the University plans with. Nevertheless, we confirmed the accuracy of the data by cross-checking samples with records kept by the School of Human and Social Studies and the Faculty of Education.

In brief, staff and student bodies look quite different, having different patterns and rates of change. While the student body has transformed quite significantly in the direction of the national racial demographic, further transformation will require greater outreach by the University to black students. Similarly, while the staff body is transforming quite slowly, further racial transformation requires confronting a number of barriers to the recruitment of black staff.

\section{Students}

Since 1994 the student body at the Pietermaritzburg campus of the University of Natal (UNP) has transformed in the direction of national demographics quite quickly. As Figure 1 illustrates, in 1994 white students comprised the majority on the campus at 61 percent but today are a minority at 26 percent, echoing Cooper and Subotsky's finding of a drop of 50000 white students countrywide between 1984 and 1998. Conversely, black student numbers at UNP have risen from 24 percent in 1994 to comprise the majority today at 54 percent. Again, this trend appears in accordance with the Cooper and Subotsky finding of a 45000 student increase in this race group countrywide. If we extrapolate from this trend the black student numbers should reflect national demographics sometime around 2030. In short, then, a first glance at 
the statistics for the student body suggests that demographic transformation is progressing well.

\section{FIGURE 1: $\quad$ Student Percentages by Race, 1994-2002}

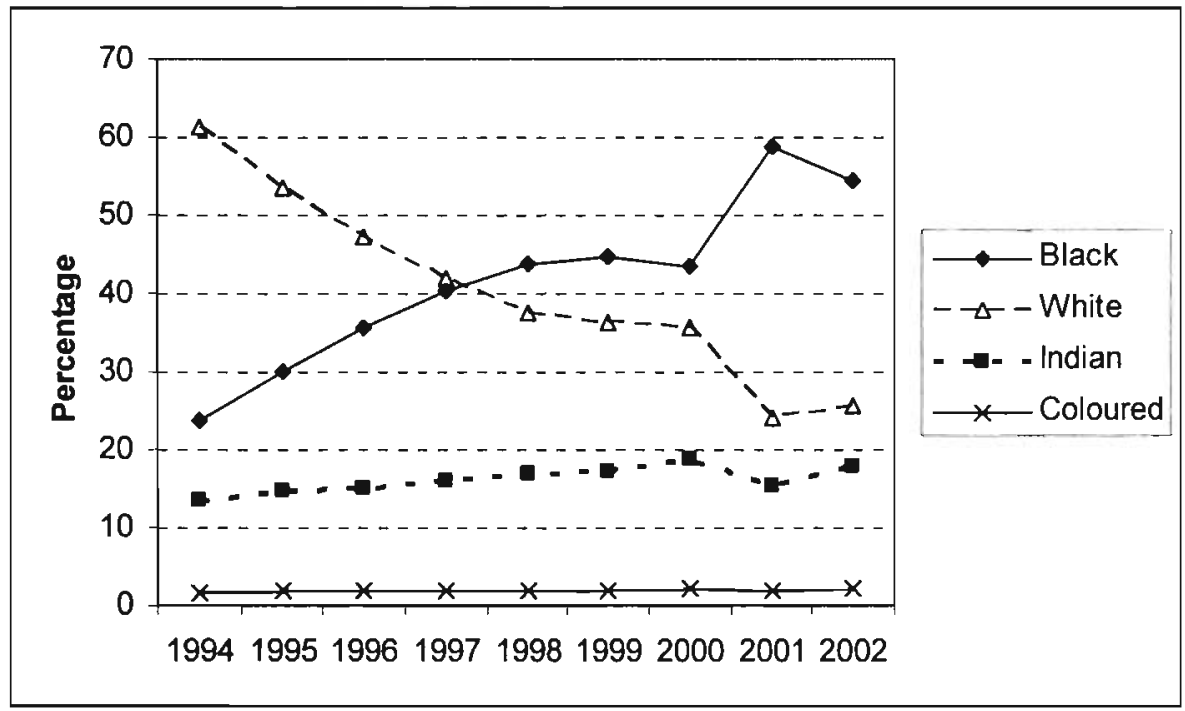

A closer inspection of the disaggregated statistics reveals that this pattern of demographic change has been uneven. Figure 2 shows demographic change that occurred in the UNP student population in the five academic faculties between 1994 and 2002. By far the greatest increase in the proportion of black students has occurred in the faculties of Education and Science and Agriculture, which have had a corresponding drop in white students. The other faculties have had smaller increases in black and Indian students alongside substantial proportional drops in white students. 
FIGURE 2: Demographic change in students by UNP faculty, 1994 2002

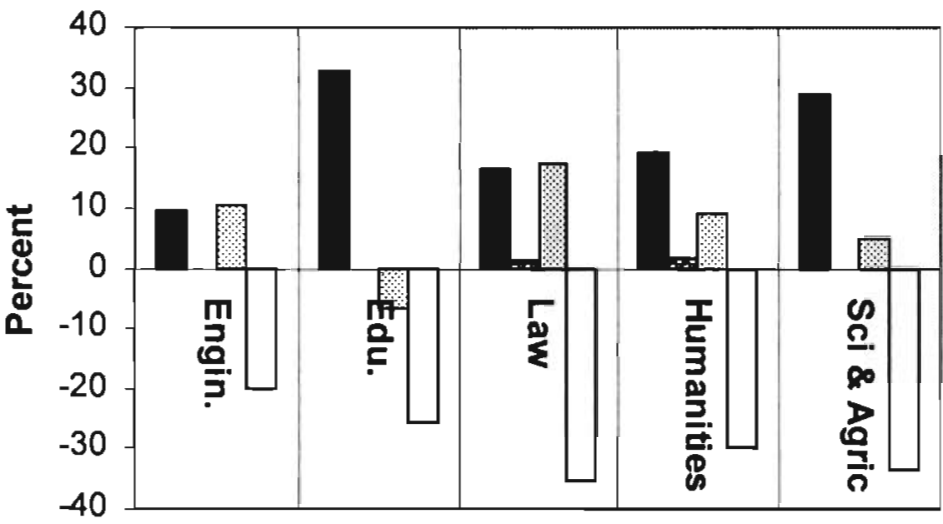

Black

Coloured

을 Inian

$\square$ White

Faculty

Potential reasons for the uneven growth across all race groups are revealed by an examination of the two faculties that have shown good growth in black students since 1994. Education and Science \& Agriculture have instituted significant outreach programmes to recruit students who would not otherwise attend the University. In the case of Education this has been through extending teaching to other centres in the province and actively recruiting teachers who are fully supported financially by the national Department of Education. The Science and Agriculture Faculty has a successful Science Foundation Programme (SFP), which recruits students who would otherwise not be accepted into University, and supports them financially throughout their degree 


\section{FIGURE 3: $\quad$ Black Students at UNP as Percentage of Total, 1994-2002}

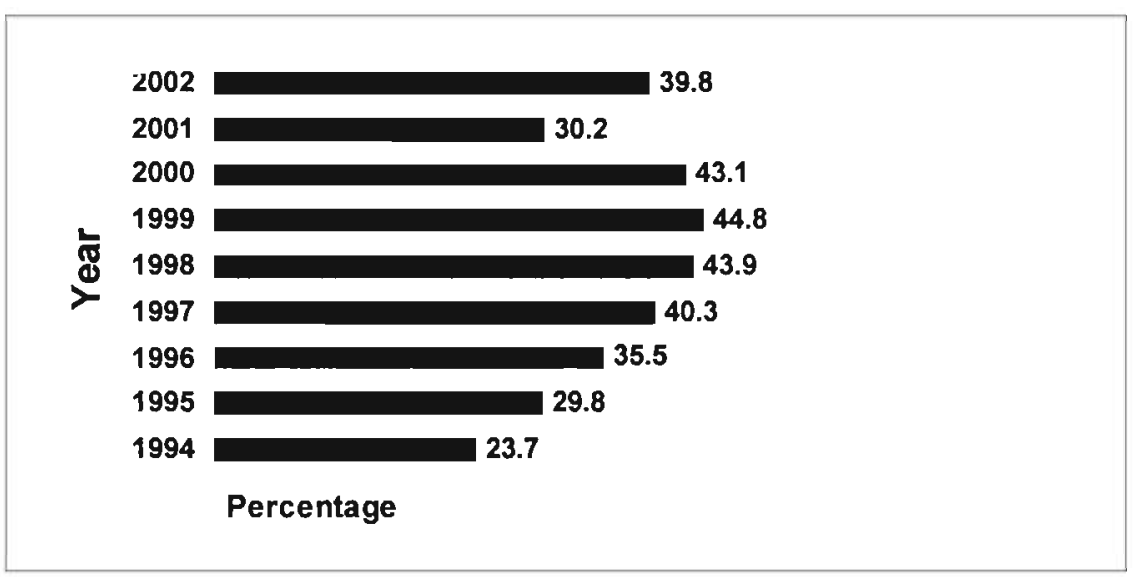

So successful has the Education Faculty been in attracting black students that nearly 50 percent of the black students registered on the Pietermaritzburg campus are in Education. Significantly, though, about 95 percent of these students are registered in mixed-mode modules run off campus. Consequently, the number of black students actually on-campus has not increased since 1999 (see Figure 3).

\section{Staff}

In 1994 the demographics of the staff body at the University of Natal was far less transformed than the student body. Moreover, it has transformed more slowly since then. As Figure 4 shows, in 1994 white staff comprised a majority of 65 percent and today continue to do so, if marginally, at 51 percent. Conversely black staff has risen from 15 percent in 1994 to 21 percent today, and Indian staff have grown from 17 percent to 24 percent. The need for racial transformation of staff is even more pronounced when one considers academic staff distinctly from non-academic staff (see Figure 5). 
FIGURE 4: $\quad$ University of Natal Staff by Race, 1994 and 2002
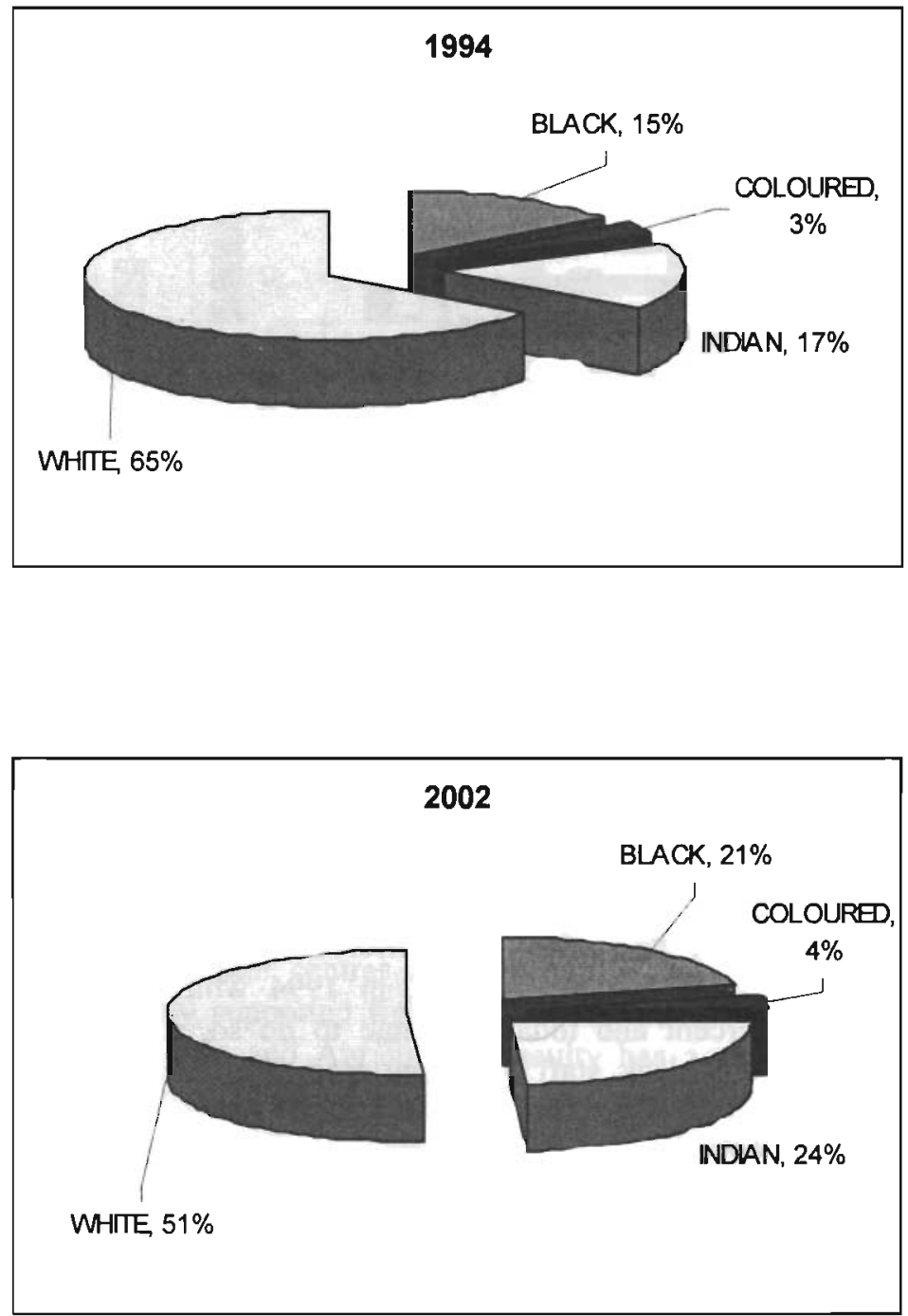
FIGURE 5: Academic versus Non-Academic Staff by Race, 1994-2002
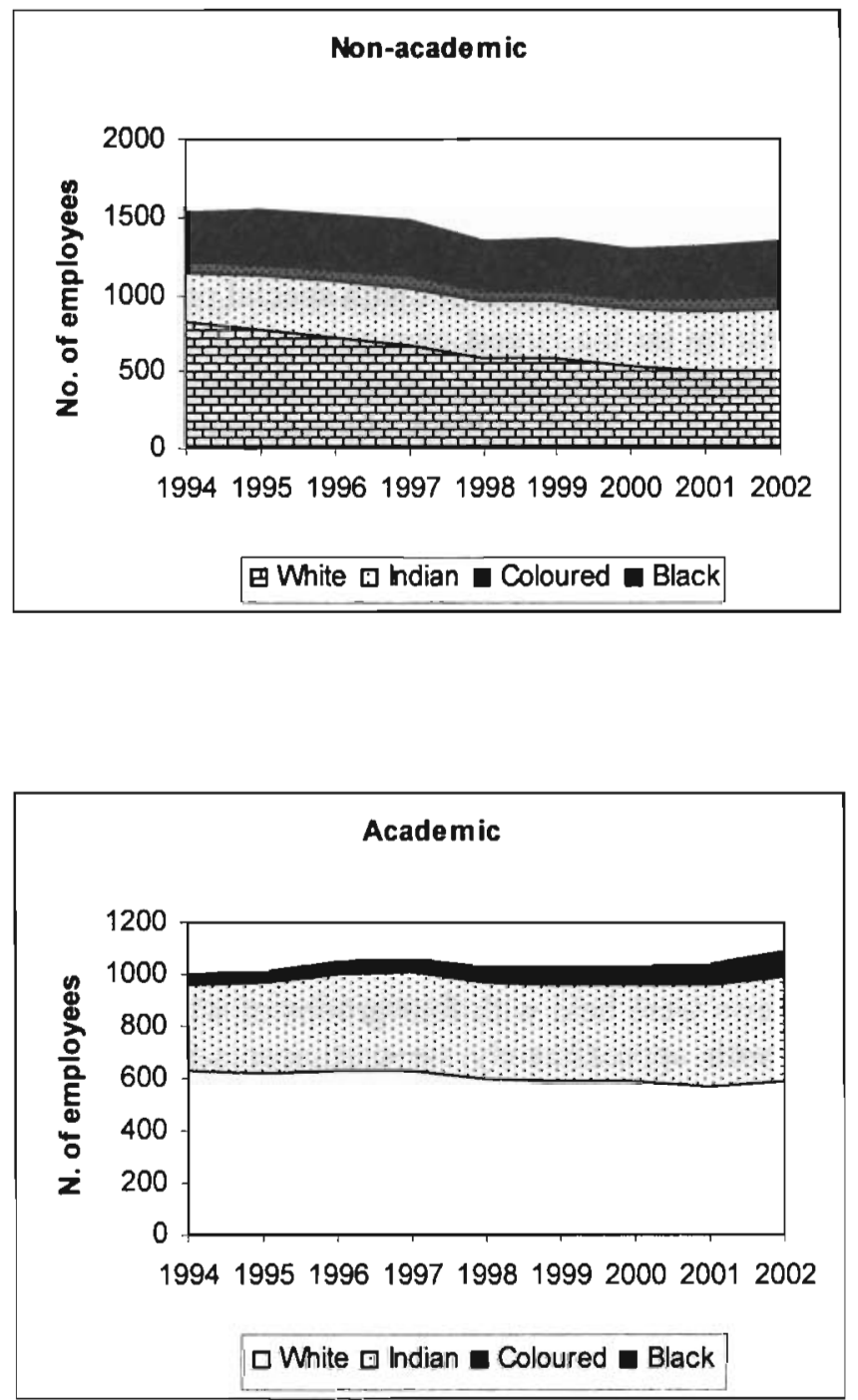
The idea behind this statistical approach was to apprise ourselves of the "facts of change', based on a quantitative perspective from University records. This analysis of race numbers for both staff and students revealed a mixed picture, reminiscent of the 'skewed revolution' that Cooper and Subotsky (2001) suggest has taken place more broadly in the tertiary education sector in South Africa. The analysis of disaggregated data shows three fault-lines of differential change. First, change in the staff body has been slower than change in the student body; with very little change occurring among academic staff. Second, change in the student body has been uneven across faculty, with more progress being made in faculties with special programmes to attract black students. Third, by far the largest change to the student body has been the vast growth in the numbers of black distance students, who account for a substantial the proportional growth in black students overall, but who are not actually physically present on campus.

\section{Student Perceptions of Racial Transformation}

We now consider student perceptions of transformation at UNP with a view to determining whether the lived experience of being on campus differed for blacks and whites. The success of University transformation could be gauged by the degree to which black and white students both experienced the campus as an integrated, equitable and non-discriminatory place. Two differing research methods were deployed to investigate student perceptions: (i) focusgroup interviews and (ii) a survey.

\section{Focus Groups}

Focus group interviews were held with four groups of white and four groups of black students, with approximately six participants in each group. The sample was selected in a purposive manner, targeting different sites of student residence, and asking for volunteers from each site to participate. A trained researcher of the same race as the participants facilitated each interview. Discussion in the interviews focussed on racial contact, segregation and experiences of racism at UNP. Participants were also asked to reflect on transformation at UNP, and to make suggestions for further change. All interviews were recorded on audiotape, and then transcribed verbatim and in full.

Descriptive thematic analysis was used to analyse the data. All interviews were read on a number of occasions and emerging themes were identified and coded, using NVivo software. Three higher-level codes were 
identified that distinguished the main themes of the discussions: (1) Perceptions of racial differences on campus and experiences and expressions of racism and racial identification; (2) Descriptions and explanations of segregation in different sites in the University, including the classroom, residences and social places; and (3) Opinions, suggestions and prescriptions about transformation at UNP. Throughout, the analysis aimed to document similarities and differences between black and white experience.

\section{Survey}

A survey of student's perceptions of transformation was also conducted in order to do a racial comparison of student's support of diversity strategies and racial contact. Self-administered questionnaires were handed out to students at various locations on campus where students congregate socially. Third year students distributed the questionnaires and assisted students in completing them. The student 'fieldworkers' approached students of the same 'race' as themselves. The data were analysed using simple cross tabulations to compare black, white and Indian students' support for diversity strategies, racial integration, cross racial communication and interaction and the importance of race in succeeding in society. The total sample for the study comprised of 210 students. Indian students made up the largest proportion of the sample ( 38 percent, $n=83$ ) followed by black students ( 32 percent, $n=69$ ) and white students ( 27 percent, $n=58$ ). These racial demographics are not representative of the total population of students at UNP which is 54 percent black, 26 percent white and 18 percent Indian. Female students outnumbered male students in the sample as a whole (by 60 percent to 40 percent) and within each racial group in the sample.

Although the sample was not randomly selected the results did support and confirm findings from the focus groups; and the two sets of data are presented together here to give a comprehensive overview of student experiences. Of course, student perceptions of racism on campus, evidenced in both the survey and focus groups, do not necessarily reflect the reality of the situation. Rather than adjudicating about whether the claims are true or not, we are primarily interested in how the context of racial interaction is constructed and how these constructions frame the experiences, evaluations and practices of the various groups on campus (see Wetherell and Potter, 1992). 


\section{Findings}

\section{Universal Experience of Segregation}

All eight focus groups articulated a detailed and intricate knowledge of racial segregation in all aspects of campus life. In the residences, blacks were segregated from whites, foreigners from locals and males from females. In addition to this within residence segregation, it was mostly black students who were accommodated in residence, whereas white students move to private offcampus 'digs' after first year, and Indian students are accommodated in their homes in Indian areas of town. Findings from the student survey supported these student accommodation patterns (See Figure 6).

\section{FIGURE 6: Term-Time Accommodation by Race}

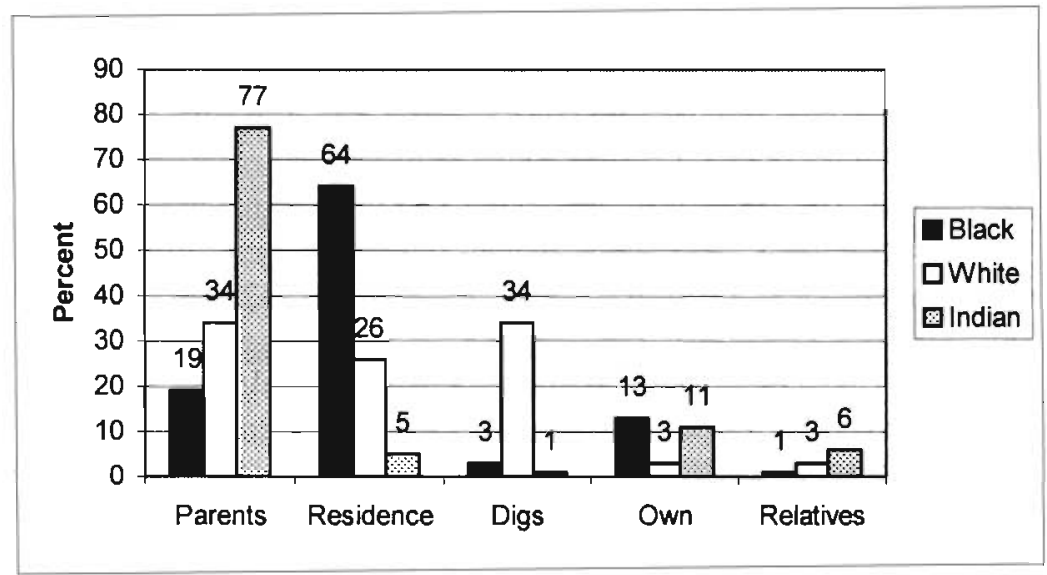

This thoroughgoing residential segregation is mirrored in segregated social and learning spaces. All groups socialize in different places both on- and offcampus; and Indian, white and black students were reported to occupy distinct spaces in lecture theatres. Remarkably, all focus groups expressed a similar detailed knowledge of the racial topography of campus. It was general knowledge that black students sit in front of the lecture theatre, Indians on the side and middle, and whites at the back. Different social spaces and residences had distinct racial reputations. For example, the library lawns were known as Bombay, one of the residences, Eleanor Russell Hall, was called Sobantu Village (after a local black township), and another, Denison, was known as Umhlanga Rocks (a wealthy, historically white suburb in Durban). 
The fact of segregation was confirmed by the student survey, in which the vast majority of students confessed to mainly intra-racial contact as opposed to cross-racial contact. Students were asked to describe who the majority of their friends on campus were, which race group they socialised with off campus, and whether they had ever dated anyone from another race group. Figure 7 shows that for all groups, the vast majority of intimate contact and on-campus social contact was racially exclusive. Interestingly though, this absence of cross-racial association contrasted with the desire, among more than 80 percent of students of all race groups, to see more integration on campus. The desire for on-campus integration is made all the more poignant by the fact that students perceive themselves as enjoying more cross-racial association off campus than on campus.

\section{FIGURE 7: $\quad$ Student Description of Racial Contact}

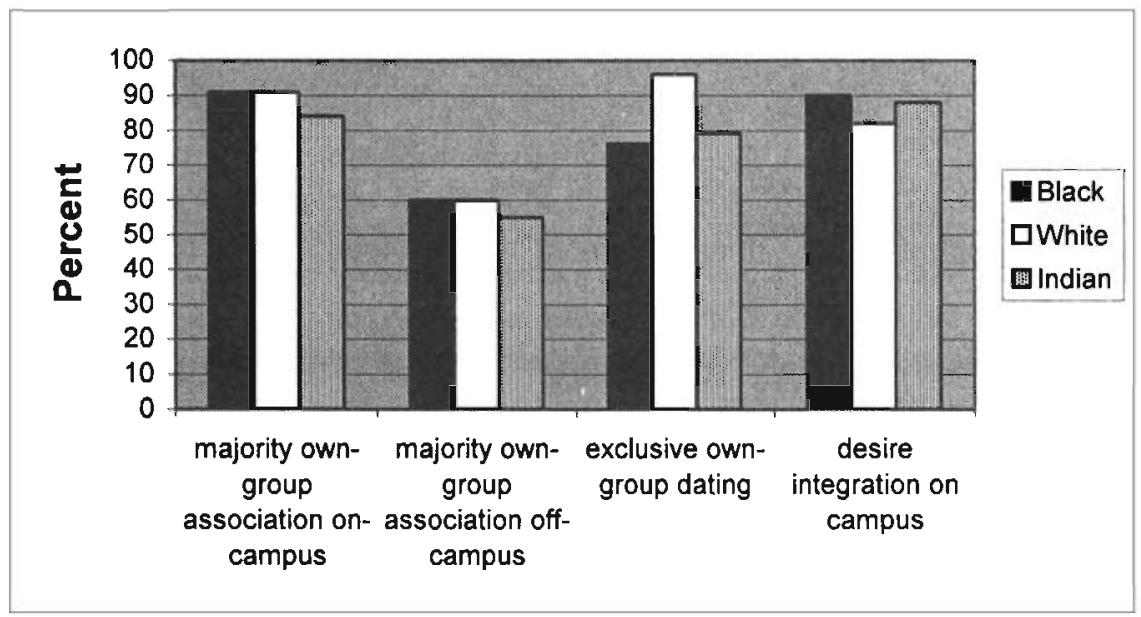

Racialised Perception of the Role of the University in Segregation

There were commonalities in the way in which the black and white groups explained the persistence of segregation on campus, but they held very different views regarding the University's responsibility for segregation. There was general agreement that segregation was to be expected, given the history of Apartheid, their own socialization in this context, and the fact that segregation of some form or another appeared to be a widespread 
phenomenon (see Durrheim and Dixon, 2000). In addition, all groups explained segregation as a consequence of cultural differences, such as tastes in music or sports preferences, which dictated racialised forms of recreation (see Buttney, 1999). Similarly, in the survey students cited different backgrounds (17 percent of black students, 28 percent of white students and 19 percent of Indian students) or different interests (22 percent, 10 percent and 13 percent respectively) as the obstacles to integration.

The focus groups also revealed significant differences between black and white perceptions of the degree to which segregation was orchestrated by University authorities. Extracts 1 and 2 show that black explanations assume the role of an organizing agent in the University, colluding with white interests; whereas white explanations focus on personal preferences (see Goldberg, 1998).

\section{Extract 1}

B(lack): For instance in our surname, like Speaker l's surname is ..., that's like, would be for an international student, and most of the time they don't know how to pronounce that so you know, they put us in Denison, for like reasons like that, and we did go there, to get our res changed, there was some white parent saying that put my kid in a white res and whatever whatever, and Elizabeth was like no we're more than willing to change the res for your child so she would be more comfortable with white people in Denison and the parents was like no I want a white res, I can't have my child living in that res, and they just put them like that.

\section{Extract 2}

W(hite): Umm, I kind agree with what Speaker 4 was saying about how, like segregation has kind of happened because of what course you do, like you find when you are in commerce ... you find that a lot because it is mainly black students and what she was saying about the agric thing more whites and commerce Indian and that's it's not anyone 's like choice with who you don't want to hang out with it just, just happens because of their courses and stuff.

Consistent with this divergence in opinion, the survey revealed that black respondents were far more supportive of University transformation policies than were Indian and white respondents. Figure 10 shows the proportion of each sample that supported five different University programmes: recruitment 
initiatives for mature students, access courses for historically-disadvantaged students, financial aid for disadvantaged students, affirmative action in staff selection, a lectureship programme for the historically-disadvantaged, and the development of an employment equity committee.

\section{Divergent Experiences of Racism}

The survey showed that only 14 percent $(n=28)$ of students felt that they had been a victim of racism on campus (19 percent of black students, 3 percent of white students and 17 percent of Indian students). The majority of students of all races felt that race had little impact on whether they did well at the University (69 percent of black students, 73 percent of white students and 55 percent of Indian students felt that it was unimportant). However, the focus groups revealed a far different experience. Not only did the black participants suggest that the institution orchestrated segregation, they also argued that it sponsored racism of various kinds. In fact, all the black groups agreed that the experience of racism was a regular part of life on campus. The most benign form of racism was feelings of discomfort that emerged from interaction with white peers (see Extract 3). Occasionally black students experienced being treated brusquely or suspiciously by white peers who, for example, would lock their car doors when seeing a black person approach. Occasionally white acquaintances were thoughtless in their comments, for example, about their 'maids'.

\section{FIGURE 8: $\quad$ Student Support for University Transformation Policy}

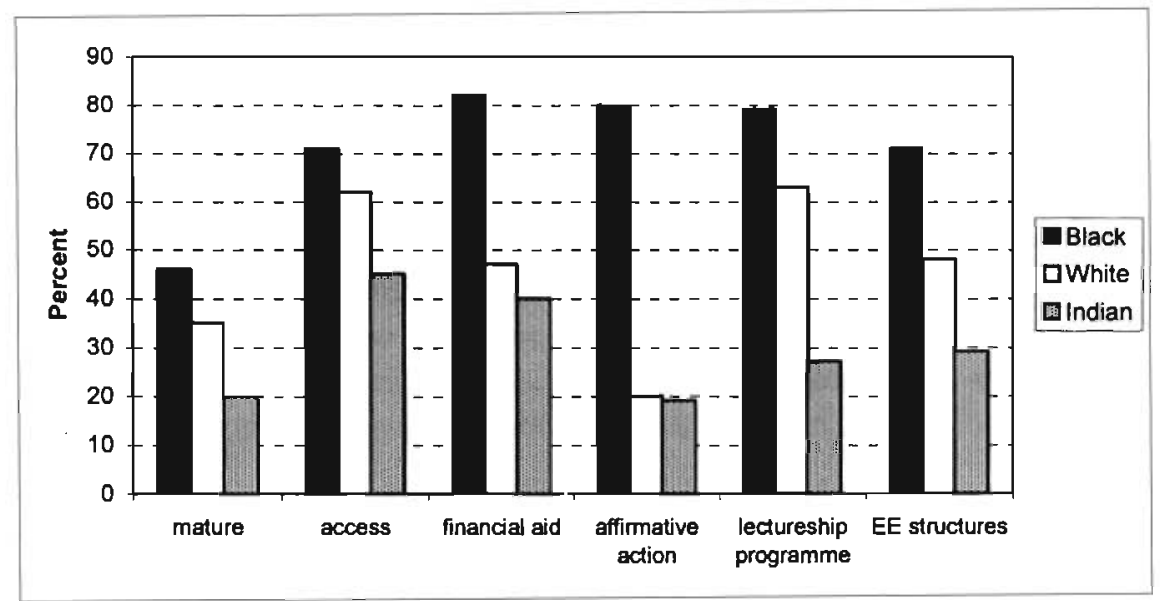


administrative staff of the University. Extracts 4 to 6 shows that black students experience their treatment by the predominantly white staff as discriminatory and stereotyped, and they argued that this had an effect on their academic performance, sense of well-being, and sense of self-esteem.

\section{Extract 3}

B: ... you know Afrikaans people don't like black people and English people sometimes pretend like it's nobody's business and they like 'oh my gosh no I like black people. I lived with this person for the past twenty years she is the part of the family'.

\section{Extract 4}

$B$ : ... even treatment from staff, it tends to be, like you know, they tend to give more attention to white people or international students as well, they get treated better than us, like you find that you are going there to inquire about something, the other person is going to get that information even give him pamphlets or whatever whatever, but they'll just tell you to go wherever and ask what you want to know.

\section{Extract 5}

$B$ : Some of the lecturers as well, like maybe when you go to them maybe you don't understand something, so when you first approach them, because they see you are black, they are thinking, oh Nkosi yam, idiot, idiot, and then when they hear that you can express yourself in English, then only they start warming a bit

\section{Extract 6}

Facilitator: How is it like ... to you as a person as a black person on campus? $B$ : well academically it's bad because not as in I can't perform good but er when it comes to the treatment from the lectures 'cos most of them as white. Er they just treat you like dirt and when you kind of complaining they like so what ... Even though you know the answer but the way he does it it's like you don't feel like answering you feel scared as if you know you are deaf or some kind of er and er ja its not good at all its bad but they do it on you.

These allegations of racism show that black students experience a sense of marginalization. Similar views were not prominent in the white interviews. Two of the white groups expressed a concern about affirmative action and 
what they perceived as favouritism towards blacks and Indians (see Extract 7). Generally, the whites explained segregation as a natural outcome of cultural differences and personal preferences, and not as a result of racism on the part of themselves, other groups or University authorities. It is interesting to note, however, that in their depiction of cultural differences, the white respondents expressed precisely the kind of offensive stereotypes that lie at the heart of blacks' experience of racism: for example, that whites deserve better housing (Extract 8) and that blacks are dirty (Extract 9). There were many such examples of racist assumptions in the white interviews; although, as Extract 9 shows, they were often couched in the language of personal reason, moderation and liberalism.

Against the background assumptions of cultural differences between blacks and whites, whites justified their withdrawal from integrated spaces as natural (see Extract 10). One of the most prominent themes of the white interviews was the desirability and necessity to seek out segregated spaces. Generally, the white groups conveyed a sense of self-assurance in their ability to carve out white spaces, for example, in moving from residences to private accommodation (Digs).

\section{Extract 7}

W: I don't think white people would mind if ... things, the whole Apartheid thing stopped. If things started from the beginning. If the black person is more qualified no one is going to ... say he doesn't deserve the job. Of course he deserves the job. But it's when someone, no matter what race they are, of a higher intelligence or qualification gets pushed out the way for someone that ... doesn't have the qualifications that's necessary.

\section{Extract 8}

W: Can I just say something. Maybe it is because traditionally black aren't used to stay in a house. Umm. Lets try and get the right point (laughter) but we are all like brought up in houses and maybe they can't afford living in houses or maybe because they have got ... financial aid or whatever, maybe it's like a step up for them and for us it is like a step down. 


\section{Extract 9}

W1: We seem to think, I mean whites seem to think that blacks live you know, they will make it dirty and they will break things and you know, you don't want to live there because, you don't want to live in a res that's all been flooded and toilets will be disgusting and this and that at the end of the day, in my first year where I lived in a whites only tower, basically umm ... the toilets got flooded the toilets got flooded and the toilets were disgusting (giggles) and it was dirty, and I hated living there and I was with white people. Umm, so ... I think the facilities are the same, we seem to think they might be different because of the people living there but it is just students.

Facilitator: Why do you think there is segregation?

W2: I think it is quite natural...

W3: ... I think it is because we all come from different cultural backgrounds. So there is quite a big gap between our way of doing things and other peoples' way of doing things so we can't really relate to each other as we would with our own race.

\section{Extract 10}

WI: It is just the way I have been brought up. The thing is if you leave varsity now and you have to go and look for a house you will go and look at areas you know and stuff. Whereas they will go and look in their areas. I just think that's the way it is. Although they still come into their areas, but I don't think whites actually come into their areas. There's more groups and stuff.

W2: I think it comes down to society and how you feel about. I mean I don't see myself as a complete and utter racist, but in general I don't like black people. I don't like to hang out with black people. Umm, you know, umm it is just the way we think we are comfortable with white people and I wouldn't want to live with a black person, even if they, they might have gone to a great school like Hilton or something or they might speak better English than I do, you know, but still at the end of the day they are a different race to me and that does bother me, like it or not really.

Overall, the interviews suggest that there are racially lopsided perceptions of transformation at UNP. The opinions diverge in a manner that reflects the pattern of racial segregation on campus. Black students believe that the University is giving a false impression to the world that it has transformed. Their daily experience of segregation and racism belies the contention that the 
University has transformed. All the black focus groups endorsed renewed and invigorated efforts at institutional change (see Figure 8). They targeted the University authorities as responsible agents, and suggested that the staff composition change, and that policies that promote segregation be dropped (see Extracts 11 and 12)

\section{Extract 11}

B:... like the higher powers in this University they're just so ... racially segregated themselves that they don't see anything wrong with it and they're just making us fall into the same pattern ....

\section{Extract 12}

Facilitator: ehm lastly but not least, what do you think the University and the students can do to ... deal with this issue of segregation?

$B$ : $O K$, first of all the University will have to to to to to to to revise their strategy of doing things. Er first of all er well of course student housing they'll have to forget looking at a a at your colour before allocate you a res.

For the most, the white participants did not express the view that transformation was necessary. Given their argument that segregation was natural, they suggested that there was not much you could do to change the situation. In places, the white students argued that attempts by the University authorities to promote change were problematic and forced, and end up excluding whites.

\section{Extract 13}

WI: Ja, if you look at your initial introduction to University, I hardly think that it was aimed at integrating the University at all. If you look at $O P$ week, it was primarily white students primarily doing the things that naughty white kids do. And there wasn't much of an attempt to be sort of, integrating.

W2: But then they have tried in the last two years to make it more integrated and to make it more black focused, to be blunt, and then it hasn't worked. It 's fallen flat.

W3: Now it's the opposite way round almost that the whites aren't participating and the blacks are.

W2: But they're not even participating as wholeheartedly. 
Facilitator: So do you think they put too much emphasis on trying to change it?

W2: I think they forced change.

W4: Can't force change.

W2: And you can't force people because if people are uncomfortable, they have to gradually get over it. You can't just throw anyone in at the deep end. Facilitator: So there's no point in doing the opposite to what they were?

W2: No cos then just get everyone backing down because they're all as scared as each other.

W1: Ja that's so true hey.

\section{Conclusion}

Despite the overall change in the demographic profile of students at the University of Natal, the impact of almost 50 years of apartheid remains apparent. In this paper, we have provided a case study of some of the faultlines along which 'revolution' in the tertiary education in South Africa has been 'skewed'. What we have captured is a brief snapshot of the attempts made by the then University of Natal to meet the national call for "transformation". In the context of national transformation, this three-pronged descriptive study of transformation at the University during the 1990s has illustrated some of the difficulties of achieving transformation, particularly in the area of racial integration. The study began with a brief description of the policy context in which South African higher education found itself and highlights some of the responses made by the University. Given this institutional framework, the paper then focused on the demographic change that has taken place within both the student and staff sectors. Finally, we offered some insight into the lived experience of students on campus who, through extracts quoted, give an indication of their perceptions of the state of transformation at the University.

On the policy front, we found that the University had produced a steady stream of policy documents targeting transformation, and that these echoed the clear and directed national policy initiatives. The University had complied with the call for higher education transformation made by government, and set out to change first staff and then student demographics. However, it appeared as though this policy response has been somewhat reactive and superficial, focusing almost exclusively on demographic change. 
Our investigation of the changing demographic composition of students and staff during the 1990s suggests that change has indeed occurred. The rate of this change has been rapid among students and slow among staff (especially academic staff). The results of change in the student body show that special programmes such as the Science Foundation Programme and the Human Sciences Access Programme have been successful in producing change.

Our qualitative study of students' experiences of life on campus raised a number of issues of serious concern. While desegregation may have taken place in terms of student demographics, true integration remains incomplete. Both black and white students perceived campus to be highly racialised and informally segregated, but they accounted for the segregation differently. White students saw segregation as a natural outcome of cultural differences, whereas blacks saw segregation as orchestrated and maintained by university authorities, who were predominantly white. Together, these divergent sets of perceptions and explanations served to justify and excuse the practices and preferences by black and white students to remain together apart.

In reproducing many of the social pathologies of apartheid race relations, segregation effectively undermines racial transformation understood as 'getting the racial numbers right' because it does not sufficiently address issues of racism. Thus while the University may have moved away from overt racist exclusion, 'informal segregation' (Dixon and Durrheim, 2003) stands squarely in the way of racial integration; and a substantially transformed University community. Indeed, as long as segregation remains, the idea that the University has successfully transformed from a racist order into an inclusive one must be questioned. This is the real practical and normative challenge to racial transformation, not 'getting the racial numbers right'. Arnove makes an associated point that "without substantial changes at the structural, cultural, and personal levels, it is unlikely that Historically Advantaged (read white) Institutions will successfully integrate students and faculty of colour and significantly overcome a history of racial segregation" (cited in Mobokela and King, 2001 :viii).

In conclusion, we suggest that more needs to be done in actively engaging with institutional transformation by developing creative and concrete strategies, not only to create a demographically representative student and staff body, but also to facilitate non-racial interactions between 
students, staff, and staff and students. Now that the first necessary step of inclusion is being addressed, policy needs to target social integration. This is the challenge for the next decade for the leadership of the new University of KwaZulu-Natal.

Kevin Durrheim (durrheim@ukzn.ac.za) is a professor in the School of Psychology at the University of KwaZulu-Natal (UKZN), South Africa. His recent work is in the area of racial identity, stereotypes and segregation. He is author (with John Dixon) of the forthcoming book, Racial encounter: The social psychology of contact and desegregation (Psychology Press, London).

Kirsten Trotter (trotterk@ukzn.ac.za) teaches in the Policy and Development Studies discipline on the Pietermaritzburg campus of UKZN. She has an M.Comm in Community-Higher Education-Service-Partnerships (CHESP) with a particular focus on citizenship and service learning. Her current research areas include policy agenda setting with particular reference to public health in South Africa as well as continued interest in service learning as a useful pedagogy for students of policy studies in the South African context.

Laurence Piper is a senior lecturer in the School of Politics, UKZN. A graduate of Cambridge with a $\mathrm{PhD}$ on Zulu nationalism, his research is thematised around 'democracy and difference'. To date he has published mostly on the IFP, Zulu nationalism, elections and politics in KwaZulu-Natal, but is looking to expand in both more national and theoretical directions.

Desiree Manicom is a senior lecturer in the Policy and Development Programme at the UKZN's Pietermaritzburg campus. Her research interest is gender and social grants. She is currently registered for her $\mathrm{PhD}$.

\section{Appendix 1: Primary Sources Used in Policy Description}

University of Natal (Private) Act, No. 7 of 1960.

Universities Amendment Act No. 123 of 1991.

Employment Equity Act no. 55 of 1998.

University of Natal. 1982. Statement of Management Policy Objectives and Strategies: Senex Minutes 30 March, Pietermaritzburg. 
1989. The Role in Society of the University of Natal: 1989 Onwards. 1989. Partners in Progress: The Role in Society of the University of Natal. 1990. Launch of Mission Statement Address by the Vice-Chancellor and Principal, Prof.

P. De V. Booysen, April, Pietermaritzburg. 1992. Vice-Chancellor's Review Working Paper Phase II. 1993. Annual Report of the Vice-Chancellor and University Principal (Part I-1993). 1995. Special Senate Minutes 7 June, Pietermaritzburg. 1995. Equal Opportunity and Affirmative Action Policy. 1995. Annual Report of the Vice-Chancellor and University Principal (Part I-1995). 1996. A University in Transformation. 1997. Strategic Initiatives for the University of Natal. 1999. Strategic Initiatives for the University of Natal. 2000. Strategic Initiatives for the University of Natal. 2000. Draft Revised Recruitment \& Selection Procedure Document. . 2001. Equal Opportunity and Employment Equity Policy, Annexure 3, Council Meeting 22 June, Durban.

2001. Strategic Initiatives for the University of Natal.

2001. Explanatory Note to Draft Equal Opportunity and Employment Equity Policy for Submission to Senate, Senate Meeting, Appendix A, 14 March, Durban.

2001. Overarching Employment Equity Plan: Employment Equity Strategy Document 2001-2005.

2002. University of Natal, Policy and Strategies for Attracting More Africans to Academia, 2002 Institutional Forum, Appendix A.

\section{References}

Buttney, R. 1999. Discursive Constructions of Racial Boundaries and Self-Segregation on Campus. Journal of Language and Social Psychology 18(3): 247-68.

Cooper, D. and G. Subotsky. 2001. The Skewed Revolution: Trends in South African Higher Education: 1988-1998. Bellville: University of the Western Cape Education Policy Unit

Cloete, N. 2002. 'Policy expectations'. In N. Cloete, R. Fehnel, P. Maassen, T. Moja, H. Perold and T. Gibbon (Eds), Transformation in Higher Education: Global Pressures and Local Realities in South Africa. Cape Town: Juta. 
Cloete, N., R. Fehnel, P. Maassen, T. Moja, H. Perold and T. Gibbon (eds). 2002. Transformation in Higher Education: Global Pressures and Local Realities in South Africa. Cape Town; Juta

Council for Higher Education Transformation. 2001. Leading Change and Managing Transformation in Higher Education: Report on Workshops for Human Resources Practitioners 2001. Pretoria: CHET.

Chisholm, L., S. Motala and S. Vally. 2003. South African Education Policy Review. Johannesburg: Heinemann.

Department of Education. 1997. Education White Paper 3: A Programme for the Transformation of Higher Education. Government Notice 1196 of 1997, vol. 386, no. 18207. Pretoria: Government Printer.

2001. Higher Education Amendment Bill. Government Notice 22440 of 2001, no. 61 .

Durrheim, K., and J. Dixon. 2000. 'Theories of culture in racist discourse'. Race and Society 3(2): 93-109.

Dixon, J., and K. Durrheim. 2003. 'Contact and the ecology of racial division: Some varieties of informal segregation'. British Journal of Social Psychology 42(1): 1-23.

Domatob, J. 1998. African Higher Education Policy: A Survey of Sub-Saharan Africa. San Francisco: International Scholars Publications.

Enders, J., and O. Fulton. 2002. Higher Education in a Globalizing World: International Trends and Mutual Observations. Dordrecht: Kluwer Academic Publishers.

Goldberg, D.T. 1998. 'The new segregation'. Race and Society 1(1): 15-32

Kaplan, B. (ed). 1994. Changing by Degrees? Equity issues in South African tertiary education. Cape Town: University of Cape Town Press.

Mabokela, O. R. 2000. Voices of Conflict: Desegregating South African Universities. New York: Routledge Falmer.

Mabokela, O, R., and K. King. 2001. Apartheid No More: Case studies of South African Universities in the Process of Transformation. Westport: Bergin and Garvey.

MacGregor, Karen. 1996. 'Students run riot on campus'. The Times Higher Education Supplement, September $20^{\text {th }}, 1996$.

MacKenzie, C. 1994. 'Black Students in "White" Universities: The Character and Provision of Liberal Higher Education Institutions in Post Apartheid South Africa'. Compare: A Journal of Comparative Education 24(1): 67-78

NCHE (National Commission on Higher Education). 1996. A Framework for Transformation. Discussion document. Pretoria: NCHE.

Murray, B.K. 1990. "Wits as an "Open" University 1939-1959: Black Admissions at the University of Witwatersrand'. Journal of Southern African Studies 16(4): 649-676.

Wetherell, M., and J. Potter. 1992. Mapping the Language of Racism: Discourse and the Legitimation of Exploitation. New York: Columbia University Press. 


\section{Notes}

1

On 1 January, 2004, the University of Natal merged with the University of Durban-Westville to form the new University of KwaZulu-Natal. Prior to this, the University of Natal comprised two separate campuses, at Pietermaritzburg (UNP) and Durban.

2

The authors recognize that racial categories are social constructions. In order to track change universities are required to collect the self-identified racial categorizations of staff and students, which reflect the racial groupings identified by the Apartheid government. We follow this practice of racial division in this paper, and thus the term "black" is not used in the black consciousness sense to include Indian and Coloureds.

The University of Natal underwent a number of Faculty restructuring processes over the period 1994-2002. Thus while Engineering, for example, is portrayed as a Faculty in Figure 2, this is not currently the case. The Information Management Division still collects their data under these groupings and it is for this reason that the figures are presented as such. 